\title{
Culturable and unculturable actinomycetes associated with the sponge Neofibularia from Bira Island, Indonesia
}

\author{
Cico Jhon Karunia Simamora ${ }^{1}$, Dedy Duryadi Solihin ${ }^{2}$ and Yulin Lestari ${ }^{2,3^{\star}}$ \\ ${ }^{1}$ Graduate School, Bogor Agricultural University, IPB Dramaga, Bogor 16680 Indonesia. \\ ${ }^{2}$ Department of Biology, Faculty of Mathematics and Natural Sciences, Bogor Agricultural University, IPB Dramaga, \\ Bogor 16680 Indonesia. \\ ${ }^{3}$ Biopharmaca Research Center, Bogor Agricultural University, Campus IPB Taman Kencana, Bogor 16151 Indonesia. \\ Email: yulinlestari@gmail.com or yulinl@ipb.ac.id
}

Received 23 September 2015; Received in revised form 24 December 2015; Accepted 16 February 2016

\begin{abstract}
Aims: The diversity of the actinomycete community associated with Neofibularia sp. from Bira Island, Indonesia, has been largely unstudied. This study was undertaken to address the paucity of information in this respect.

Methodology and results: Culturable actinomycetes were isolated and cultured on HV medium. Polymerase chain reaction-denaturing gradient gel electrophoresis (PCR-DGGE) targeting the metagenomic 16S rRNA was used to analyse the structure of the actinomycete community. Five culturable actinomycetes that were isolated belonged to the genus Streptomyces. They showed various degrees of similarity to the reference strains Streptomyces sampsonii (9799\%), Streptomyces resistomycificus (97-99\%), Streptomyces gougerotii (97-99\%), Streptomyces erringtonii (97-99\%), and Streptomyces albus (97-99\%). The culturable actinomycetes isolates also showed differences in morphological characteristics as compared with the reference strains. The metagenomic analysis suggested that the actinomycete community was dominated by rare actinomycetes. Eight DGGE DNA bands that were obtained had sequences that showed similarities to Ferrithrix thermotolerans (88-94\%), Lamia majanohamensis (87-92\%), Aciditerrimonas ferrireducens (87-92\%), and Thermobispora bispora (85-92\%), while 4 bands had sequences similar to Propionibacterium acnes (97-100\%) and another band matched sequences belonging to an uncultured bacterium clone $(86-87 \%)$. The actinomycetes detected by the metagenomic approach were assigned identities that were mostly under $97.5 \%$ as compared with reference strains available in Genbank.

Conclusion, significance and impact of study: Observations from both culture and DGGE analysis give a better understanding of the diversity and community structure of actinomycetes associated with Neofibularia sp. The culturable actinomycetes were Streptomyces spp., while rare actinomycetes were dominant when the metagenomic approach was adopted. Several of these actinomycetes showed identities below $97 \%$ when matched to reference strains, indicating possible novel species associated with the sponge Neofibularia.
\end{abstract}

Keywords: Actinomycetes, culturable, DGGE, Neofibularia sp., unculturable

\section{INTRODUCTION}

Sea sponges are ancient sessile organisms that have existed since 600 million years ago and are important members in the coral reef ecosystem. Owing to its geographical location between the Indian and Pacific Oceans, Indonesia has a high diversity of sponges belonging to 830 species across various families (Hutomo and Moosa, 2005). Neofibularia sp. has been reported as a producer of antileishmanial, antimalarial, and antibacterial compounds (Thompson and Gallimore, 2013). Such bioactive compounds produced by sponges may have arisen from their associated microbes (Peraud, 2006). Microbe density in sponges can reach up to $10^{9}$ cells per $\mathrm{cm}^{3}$, covering $35 \%$ of the total biomass of sponge tissue (Hentschel et al., 2012). Close association between sponges and microbes (Hentschel et al., 2003) may also contribute to the high diversity of sponge-associated bacteria, including actinomycetes (Sun et al., 2010).

Actinomycetes play an important role in the growth and development of sponges they are associated with, such as by providing nutrients, UV protection, defence against toxic compounds, and by stabilizing their skeletons, and decomposing residual metabolites (Shick and Dunlap, 2002). Various compounds are produced by different actinomycetes (Pathirana et al., 1992), and the structures of bioactive compounds produced by marine spongeassociated actinomycetes can be different from those produced by their terrestrial counterparts (Drummond, 2006).

\section{${ }^{*}$ Corresponding author}


The community structure of actinomycetes associated with sponge has yet to be extensively explored. Appropriate cultivation techniques are required to increase growth opportunities for the less abundant culturable actinomycetes on sponge tissue. Culturable microbes are thought to constitute less than 1\%; while the other $99 \%$ are unculturable microbes (Webster et al., 2001). As unculturable actinomycetes cannot be identified morphologically, the metagenomic approach is often adopted.

In this paper, the community structures of both culturable and unculturable actinomycetes were assessed using the metagenomic approach based on the 16S rRNA gene. The amplified 16S rRNA gene was subjected to denaturing gradient gel electrophoresis (DGGE) to separate genes of the similar size (Fischer and Lerman, 1983). DNA finger printing of PCR-amplified rDNA using methods such as DGGE provides information about the community structure of actinomycetes. In DGGE analysis, DNA fragments with the same length but different nucleotide sequences are separated based on the differences in mobility of PCR-amplified DNA molecules in polyacrylamide gels in a linear denaturing gradient (Muyzer et al., 1993). Sequence comparisons can then be made against reference strains available in the GenBank database.

The structure of the actinomycetes community associated with Neofibularia sp. based on the metagenomic approach had not been reported; hence, the present study was undertaken. In combination with culture on synthetic media for culturable isolates, the two different approaches would provide better information regarding the actinomycete community associated with sponge Neofibularia sp. from Bira Island, Indonesia.

\section{MATERIALS AND METHODS}

\section{Sponge sampling}

Marine sponges were obtained by scuba diving in 4 to 8 meter deep water off Bira Island $\left(5^{\circ} 23^{\prime}-5^{\circ} 40^{\prime} \mathrm{S}, 106^{\circ} 25^{\prime}\right.$ $106^{\circ} 37^{\prime} \mathrm{E}$ Northern Jakarta) which belongs to the Kepulauan Seribu group of islands $\left(5^{\circ} 24^{\prime}-5^{\circ} 45^{\prime} \mathrm{S}, 106^{\circ}\right.$ $\left.25^{\prime}-106^{\circ} 40^{\prime} \mathrm{E}\right)$, covering an area of 107.489 ha. The sponges were identified as Neofibularia sp.

\section{Isolation and morphological characterisation of culturable actinomycetes}

Culturable actinomycetes were isolated and cultured on Humic Acid Vitamin B Agar (HV Agar). About $1 \mathrm{~g}$ of sponge sample was crushed and serial dilutions up to $10^{-3}$ were carried out. A suspension $(0.1 \mathrm{~mL})$ each was taken from $10^{-1}, 10^{-2}$ and $10^{-3}$ dilutions, spread on HV Agar, and then incubated at $26-28{ }^{\circ} \mathrm{C}$ for 4 to 8 weeks. Colonies of actinomycetes were purified using Yeast Starch Agar (YSA), a selected actinomycetes medium, for 10 days at $26-28^{\circ} \mathrm{C}$. The colonies were morphologically characterized based on macroscopic (pigmentation and colour of colony) and microscopic (Gram staining, aerial hypha type, and abundance of aerial mycellia) observations using an Olympus Optilab microscope at 400x magnification. Colonies with abundance of aerial mycellia, filamentous cell and gram positive reaction were indicative of Streptomyces spp.

\section{Genomic DNA isolation from culturable actinomycetes}

Isolation of actinomycete genomic DNA was performed according to the Geneaid Genomic DNA Mini Kit protocol (Blood/Cultured Cell). Purity $(\lambda 260 / 280=1.8-2)$ and the DNA concentration was then measured using the Nanodrop 2000 spectrophotometer (Thermo Scientific, Wilmington, DE, USA).

\section{Metagenomic DNA isolation of actinomycetes associated with Neofibularia sp.}

One gram of sponge sample was crushed into powder in liquid nitrogen, followed by the extraction of total genomic DNA using the Power Soil DNA Isolation Kit (Mobio Laboratories, Carlsbad, CA, USA). The purity and the quantity of the extract were measured as described above.

The 16S rRNA gene amplification of culturable and unculturable actinomycetes from Neofibularia sp.

Genomic DNA was amplified by the polymerase chain reaction (PCR) using the T1-thermocycler (Biometra, Goettingen, Germany). Genomic DNA was used as the template for amplification using two 16S rRNA gene primers specific for actinomyces, i.e. 27F (5'-AGAGTT TGATCCTGGCTCAG-3') and 16Sact1114R (5'GAGTTGACCCCGGCRGT-3') (Martina et al., 2008).

The $25 \mu \mathrm{L}$ reaction volume consisted of $12.5 \mu \mathrm{L}$ GoTaq Green Master Mix $2 \times, 0.25 \mu \mathrm{L}$ of each primer (60 pmol), 5 $\mu \mathrm{L}$ template DNA (100 $\mathrm{ng} / \mu \mathrm{L})$ and $7 \mu \mathrm{L}$ nuclease free water. Temperature gradients used for PCR were as follows: $5 \mathrm{~min}$ pre-denaturation at $94{ }^{\circ} \mathrm{C}, 1 \mathrm{~min}$ denaturation at $94{ }^{\circ} \mathrm{C}, 45 \mathrm{sec}$ annealing at $65{ }^{\circ} \mathrm{C}$ (decreasing $0.5^{\circ} \mathrm{C}$ for each cycle until the $20^{\text {th }}$ cycle, $55^{\circ} \mathrm{C}$ for the next 10 cycles), 2 min elongation at $72{ }^{\circ} \mathrm{C}, 7 \mathrm{~min}$ post elongation at $72{ }^{\circ} \mathrm{C}$, and 15 min cooling at $4{ }^{\circ} \mathrm{C}$ (touch down amplification). PCR was performed over 30 cycles (Zhang et al., 2013) and the products electrophorized on $1 \%$ agarose gel. A single DNA band per sample was observed in the G:BOX gel documentation system (Syngene, Frederick, MD, USA) to observe the $1087 \mathrm{bp}$ target DNA band.

The product of first phase PCR was used as template DNA for the second phase PCR using the universal primer for bacteria, i.e. P338F-GC (5'-CGCCCGCCGCGCGCG GCGGGCGGGGCGGGGGCACGGGGGGACTCCTACGG GAGGCAGCAG-3') and P518R (5'-ATTAC CGCGGCTGCTGG-3') (Overeas et al., 1997). A PCR reaction volume of $100 \mu \mathrm{L}$ consisted of $62.5 \mu \mathrm{L}$ GoTaq Green Master Mix 2× (Promega, Madison, WI, USA), 0.5 $\mu \mathrm{L}$ of each primer (100 pmol), $0.2 \mu \mathrm{L}$ of the product of first phase PCR, and $36.3 \mu \mathrm{L}$ nuclease free water. PCR for the $16 \mathrm{~S}$ rRNA gene was conducted over 30 cycles that 
consisted of $5 \mathrm{~min}$ pre-denaturation at $94{ }^{\circ} \mathrm{C}, 1 \mathrm{~min}$ denaturation at $94^{\circ} \mathrm{C}, 45 \mathrm{sec}$ annealing at $55^{\circ} \mathrm{C}, 1 \mathrm{~min}$ elongation at $72{ }^{\circ} \mathrm{C}$, and $5 \mathrm{~min}$ post elongation at $72{ }^{\circ} \mathrm{C}$. The PCR products $(5 \mu \mathrm{L})$ were run on $1 \%$ agarose gel for $45 \mathrm{~min}$ at $80 \mathrm{~V}$. The electrophoresis results were visualized after Ethidium Bromide (EtBr) staining and 180 bp bands were observed on the G:BOX gel documentation system (Syngene, Frederick, MD, USA).

\section{DGGE analysis of the 16S rRNA gene}

The PCR product of $16 \mathrm{~S}$ rRNA gene was run on to a 0.75 $\mathrm{mm}$ vertical gel containing $8 \%(\mathrm{w} / \mathrm{v})$ polyacrylamide (acrylamide-bisacrylamide (37.5: 1)) in 1x Tris-acetateEDTA (TAE). The denaturant gradient concentrations used were $30 \%$ and $70 \%$ (100\% denaturant in accordance with $7 \mathrm{M}$ urea and $40 \%$ formamide deionisation). Electrophoresis was conducted for $7 \mathrm{~h}$ at $60{ }^{\circ} \mathrm{C}, 150 \mathrm{~V}$ using the $D$ Code Universal Mutation Detection System (Bio-Rad, Hercules, CA, USA). The electrophoresis gel was stained in the dark with EtBr for $30 \mathrm{~min}$, followed by rinsing with $500 \mathrm{~mL}$ of $1 \times$ TAE buffer before observing the bands in the G:BOX gel documentation system (Syngene, Frederick, MD, USA). Separated bands were cut using a sterile scalpel and placed into micro tubes containing 100 $\mu \mathrm{L} \mathrm{dd}_{2} \mathrm{H}_{2} \mathrm{O}$. The products of DGGE were incubated at $4{ }^{\circ} \mathrm{C}$ overnight, and then incubated again at $60^{\circ} \mathrm{C}$ for $2 \mathrm{~h}$, following the conditions and primers used in the second phase PCR but without the GC-clamp (Learn-Han et al., 2012).
16S rRNA gene sequencing for culturable and unculturable actinomycetes, bioinformatic analysis and construction of phylogenetic tree

The PCR products of the 16S rRNA gene of culturable and unculturable actinomycetes isolated from sponge were sequenced following standard protocols of DNA sequencing ( $A B I$ PRISM 3100). The sequencing results were compared to those of reference strains available in the GenBank (http://www.ncbi.nlm.nih.gov/) using the BLAST program. Phylogenetic analysis was conducted using MEGA 6 software, and the phylogenetic tree was constructed using a 1000 replication-bootstrap analysis and the neighbour-joining method (Saitou and Nei, 1987).

\section{RESULTS}

\section{Diversity in culturable actinomycetes}

A total of 20 actinomycete isolates were successfully grown in HV Agar medium and purified using YSA medium. The isolates NOAq 1.1, NRSw 4.1, NOAq 1.3, NOAq 2.1, and NOAq 1.4 showed gram (positive) staining and the type of aerial mycelia including spore chainbearing aerial hyphae characteristic of Streptomyces spp. (Shirling and Gottlieb, 1966). At the same time, there were differences in colony macroscopic appearance, colony colouration and pigmentation (Figure 1, Table 1).

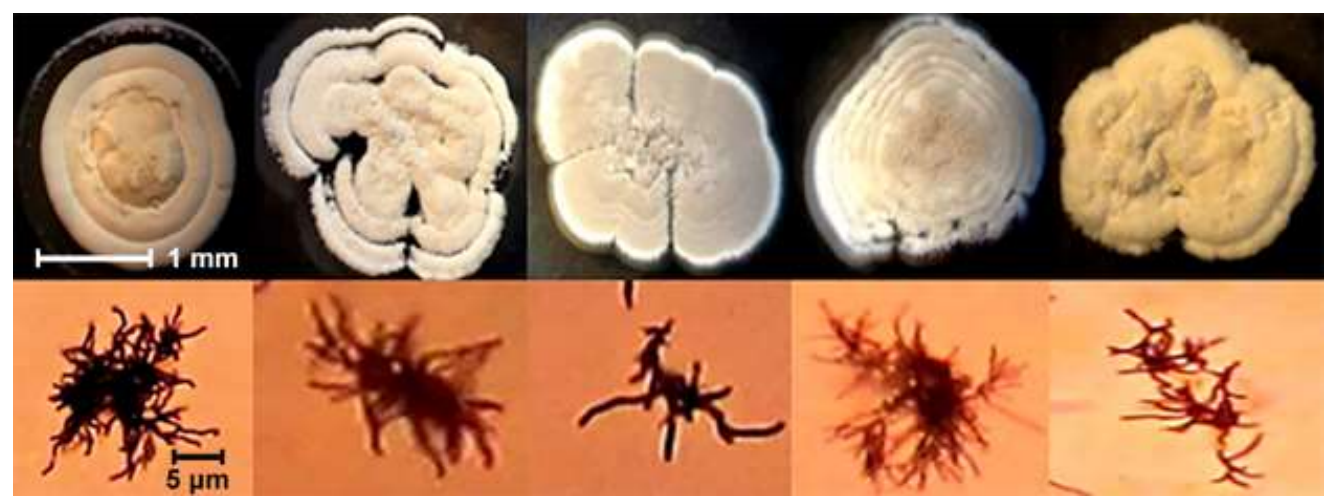

Figure 1: Macroscopic appearance of culturable actinomycetes associated with Neofibularia sp. showing different colony colouration (upper) and microscopic observations of actinomycetes (below). Isolates were grown on ISP 2 medium and observed after 10 days incubation at room temperature (Olympus Optilab, 400x magnification) $(A=N O A q 1.1 ; B=$ NRSw $4.1 ; C=$ NOAq 1.3; $D=$ NOAq 2.1; $E$ = NOAq 1.4).

The 16S rRNA genes from the genomic DNA of five isolates were successfully amplified using $27 \mathrm{~F}$ and 16Sact1114R primers with the $1087 \mathrm{bp}$ DNA fragment as the target (Figure 2A). Based on the sequence data and BLAST analysis, all isolates had sequences homologous with the Streptomyces genus. Phylogenetic analysis indicated that the five isolates belonged to a cluster of the family Streptomyceae (Figure 2B). NCBI BLAST results of the culturable actinomycetes isolates NOAq1.1, NRSw 4.1, NOAq 1.3, and NOAq 2.1 showed $99 \%$ similarity with
S. sampsonii strain NRRL B12325, S. albus strain J1074, and $S$. resistomycificus strain ISP 5133, while NOAq 1.4 was $97 \%$ similar to these reference strains. NOAq 1.1 and NOAq 2.1 were $99 \%$, NRSw 4.1 and NOAq 1.3 was $98 \%$, and NOAq 1.4 was $97 \%$ similar to S. erringtonii strain I36. On the other hand, NOAq 1.1 and NOAq 2.1 were $99 \%$, NOAq 1.3 was $98 \%$, while NRSw 4.1 and NOAq 1.4 were $97 \%$ similar to $S$. gougerotii strain NBRC 13043 (Table 2). 
Table 1: Morphological characteristics of selected actinomycete colonies associated with Neofibularia sp.

\begin{tabular}{|c|c|c|c|c|c|c|}
\hline \multirow{2}{*}{$\begin{array}{l}\text { Code of } \\
\text { Isolate }\end{array}$} & \multicolumn{2}{|c|}{ Colour } & \multirow[b]{2}{*}{ Pigmentation } & \multirow[b]{2}{*}{ Aerial Mycellia } & \multirow{2}{*}{$\begin{array}{l}\text { Gram } \\
\text { Staining }\end{array}$} & \multirow[b]{2}{*}{ Hypha Type } \\
\hline & $\begin{array}{l}\text { Surface } \\
\text { Colony }\end{array}$ & $\begin{array}{l}\text { Colony } \\
\text { Base }\end{array}$ & & & & \\
\hline NOAq 1.1 & $\begin{array}{l}\text { reddish } \\
\text { white }\end{array}$ & $\begin{array}{l}\text { reddish } \\
\text { brown }\end{array}$ & red brick & abundant & $\begin{array}{c}\text { Gram } \\
\text { positive }\end{array}$ & Rectiflexibiles \\
\hline NRSw 4.1 & white & light brown & no pigmentation & abundant & $\begin{array}{c}\text { Gram } \\
\text { positive }\end{array}$ & Rectiflexibiles \\
\hline NOAq 1.3 & brown gray & $\begin{array}{l}\text { blackish } \\
\text { brown }\end{array}$ & light brown & abundant & $\begin{array}{c}\text { Gram } \\
\text { positive }\end{array}$ & Rectiflexibiles \\
\hline NOAq 2.1 & white gray & light brown & no pigmentation & abundant & $\begin{array}{c}\text { Gram } \\
\text { positive }\end{array}$ & Rectiflexibiles \\
\hline NOAq 1.4 & cream & $\begin{array}{l}\text { reddish dark } \\
\text { brown }\end{array}$ & $\begin{array}{l}\text { reddish dark } \\
\text { brown }\end{array}$ & abundant & $\begin{array}{c}\text { Gram } \\
\text { positive }\end{array}$ & Rectiflexibiles \\
\hline
\end{tabular}

After 10 days incubation at temperature room on YSA medium

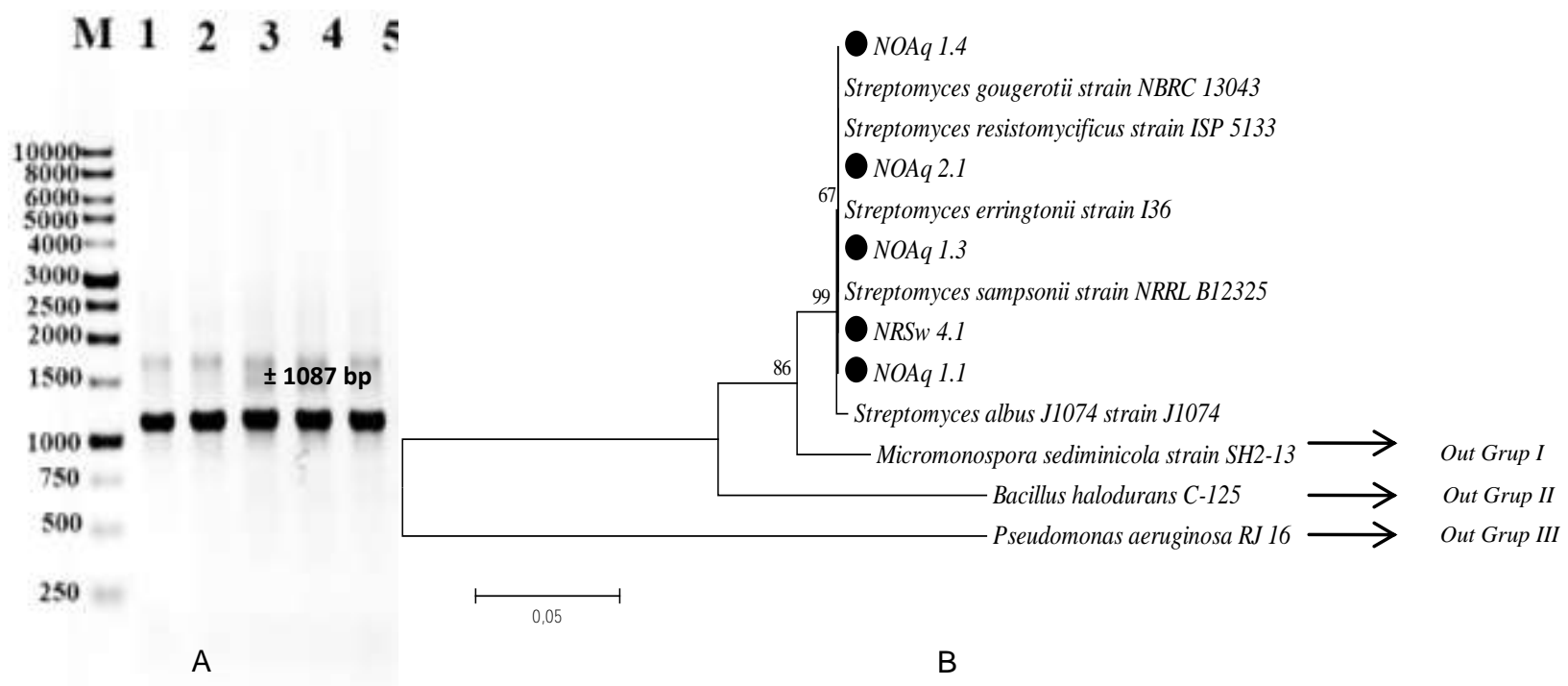

Figure 2: (A) PCR amplification of 16S rRNA (1087 bp amplicon) with primer 27F and 16Sact1114R. Lanes: $1 \mathrm{~Kb}$ marker (M), NOAq 1.1 (1), NRSw 4.1 (2), NOAq 1.3 (3), NOAq 2.1 (4), and NOAq 1.4 (5). (B) Phylogenetic tree of 16S rRNA gene of actinomycetes associated with Neofibularia sp. constructed using MEGA 6 software. Diversity of actinomycetes based on metagenomic
16S rRNA-targeted PCR-DGGE analysis

DNA extracted from sponge tissue was successfully amplified for the $1087 \mathrm{bp}$ 16S rRNA gene target. The amplicons obtained were then used as a template in the second phase of PCR to amplify the bacteria $\mathrm{V} 3$ region for a 180 bp gene target (Overeas et al., 1997) (Figure 3A). The 16S rRNA gene amplicons were separated using DGGE. Phoretix analysis, using 1D Phoretix Software, detected 30 DGGE bands (Figure 3B), including13 dominant bands that were successfully separated on polyacrylamide gel. The DGGE bands on the gel differed in thickness and stain intensity, reflecting varying abundance of the amplicons. Bands 5, 4, and 17 were thicker than the other DNA bands (Table 3). The alignment of 13 DNA bands with reference sequences in the GenBank Database indicated that bands 13, 14, 17, and 12 were $94 \%$, whereas band 20 was $92 \%$, band 6 and 3 were $93 \%$, and band 11 was $88 \%$ similar to $F$. thermotolerans strain Y005 (Figure 4). Bands 13, 6, 12, 3, 17 , and 14 were $92 \%$, band 20 was $90 \%$, and band 11 was $87 \%$ similar to $L$. majanohamensis strain NBRC 102561. Bands 13, 12, 3, 14, and 17 were also $92 \%$, band 20 and 6 were $91 \%$, band 11 was $87 \%$ similar to $A$. ferrireducens strain IC-180. Band 11 was also $85 \%$ similar to $T$. bispora strain DSM43833. DNA band 1 and 4 were $94 \%$, band 5 was $100 \%$, and band 9 was $95 \%$ similar to $P$. acnes strain KPA171202. Band 7 was $87 \%$ 
and $86 \%$ similar to uncultured bacterium clone nbw337c09c1 and ncm69a12c2, respectively (Table 4).

As mentioned previously, the DGGE bands were different in thickness, indicating different isolate abundance. Band 5 which was similar to $P$. acnes strain KPA171202 had the highest abundance, with a concentration of $19.95 \mathrm{ng} / \mu \mathrm{L}$, while band 17 , which was similar to $F$. thermotolerans strain Y005, had a concentration of $11.75 \mathrm{ng} / \mu \mathrm{L}$. Band 4 also had high abundance, at $13.45 \mathrm{ng} / \mu \mathrm{L}$. However, its identity is yet to be firmly established using phylogenetic analysis and it is possibly a novel and unknown actinomycetes community from the sponge Neofibularia.

Table 2: Similarity of culturable actinomycetes to GeneBank references strains based on 16S rRNA sequences.

\begin{tabular}{|c|c|c|c|c|c|}
\hline $\begin{array}{l}\text { Code of } \\
\text { Isolate }\end{array}$ & Description & $\begin{array}{c}\text { Total Base } \\
\text { (Isolate/GenBank) }\end{array}$ & $\begin{array}{l}\text { Position } \\
\text { Ordinal } \\
\text { Base } \\
\end{array}$ & Identity & $\begin{array}{l}\text { Acession } \\
\text { Number }\end{array}$ \\
\hline \multirow{5}{*}{$\begin{array}{l}\text { NOAq } 1.1 \\
\text { and NOAq } \\
\quad 2.1\end{array}$} & $\begin{array}{l}\text { S. sampsonii strain } \\
\text { NRRL B12325 }\end{array}$ & 997 / 997 & $45-1077$ & $99 \%$ & NR1165081 \\
\hline & \multirow{2}{*}{$\begin{array}{l}\text { S. albus strain } \mathrm{J} 1074 \\
\text { S. resistomycificus strain } \\
\text { ISP } 5133\end{array}$} & 997 / 997 & 84-1116 & $99 \%$ & NR1029491 \\
\hline & & 997 / 997 & $34-1066$ & $99 \%$ & NR0421001 \\
\hline & \multirow{2}{*}{$\begin{array}{l}\text { S. erringtonii strain I36 } \\
\text { S. gougerotii strain } \\
\text { NBRC } 13043\end{array}$} & 997 / 997 & $44-1075$ & $99 \%$ & NR1156831 \\
\hline & & 997 / 997 & $62-1093$ & $99 \%$ & NR1126101 \\
\hline \multirow{5}{*}{ NRSw 4.1} & $\begin{array}{l}\text { S. sampsonii strain } \\
\text { NRRL B12325 }\end{array}$ & $1006 / 997$ & $45-1077$ & $99 \%$ & NR1165081 \\
\hline & \multirow{2}{*}{$\begin{array}{l}\text { S. albus strain } \mathrm{J} 1074 \\
\text { S. resistomycificus strain } \\
\text { ISP } 5133\end{array}$} & $1006 / 997$ & 84-1116 & $99 \%$ & NR1029491 \\
\hline & & $1006 / 997$ & $34-1066$ & $99 \%$ & NR0421001 \\
\hline & S. erringtonii strain I36 & $1006 / 997$ & $44-1075$ & $98 \%$ & NR1156831 \\
\hline & $\begin{array}{l}\text { S. gougerotii strain } \\
\text { NBRC } 13043\end{array}$ & $1006 / 997$ & $62-1093$ & $97 \%$ & NR1126101 \\
\hline \multirow{5}{*}{ NOAq 1.3} & $\begin{array}{l}\text { S. sampsonii strain } \\
\text { NRRL B12325 }\end{array}$ & 1007 / 997 & $45-1077$ & $99 \%$ & NR1165081 \\
\hline & \multirow{2}{*}{$\begin{array}{l}\text { S. albus strain } \mathrm{J} 1074 \\
\text { S. resistomycificus strain } \\
\text { ISP } 5133\end{array}$} & 1007 / 997 & 84-1116 & $99 \%$ & NR1029491 \\
\hline & & 1007 / 997 & $34-1066$ & $99 \%$ & NR0421001 \\
\hline & \multirow{2}{*}{$\begin{array}{l}\text { S. erringtonii strain I36 } \\
\text { S. gougerotii strain } \\
\text { NBRC } 13043\end{array}$} & 1007 / 997 & $44-1075$ & $98 \%$ & NR1156831 \\
\hline & & 1007 / 997 & $62-1093$ & $98 \%$ & NR1126101 \\
\hline \multirow{5}{*}{ NOAq 1.4} & $\begin{array}{l}\text { S. sampsonii strain } \\
\text { NRRL B12325 }\end{array}$ & 1022 / 997 & $45-1077$ & $97 \%$ & NR1165081 \\
\hline & \multirow{2}{*}{$\begin{array}{l}\text { S. albus strain } \mathrm{J} 1074 \\
\text { S. resistomycificus strain } \\
\text { ISP } 5133\end{array}$} & 1022 / 997 & 84-1116 & $97 \%$ & NR1029491 \\
\hline & & 1022 / 997 & $34-1066$ & $97 \%$ & NR0421001 \\
\hline & \multirow{2}{*}{$\begin{array}{l}\text { S. erringtonii strain I36 } \\
\text { S. gougerotii strain } \\
\text { NBRC } 13043\end{array}$} & 1022 / 997 & $44-1075$ & $97 \%$ & NR1156831 \\
\hline & & 1022 / 997 & $62-1093$ & $97 \%$ & NR1126101 \\
\hline
\end{tabular}




\section{DISCUSSION}

\section{Characterization of culturable actinomycetes}

Streptomyces dominated the cultivable isolates in this study, mostly due to the isolation media and incubation temperature being suited to this genus (Vieira and Nahas, 2005). Moreover, Humic Acid Agar used in the culture is conducive to the selection for actinomycetes as it suppresses the growth of fast-growth bacteria and provides nutrition for actinomycetes,

Phylogenetic analysis based on 16S rRNA gene sequence indicated that the five culturable actinomycete isolates were most similar to $S$. sampsonii strain NRRL B12325 (NR1165081), S. resistomycificus strain ISP 5133 (NR0421001), S. albus strain J1074 (NR1029491), S. gougerotii strain NBRC 13043 (NR1126101), and $S$. erringtonii strain I36 (NR1156831). Although molecular identification showed high similarity with reference strains, dissimilarities in morphologycal character were also noted. This suggests that the culturable actinomycetes isolates might be different from the reference strains. The $S$. sampsonii colony is thin and yellowish white with a smooth colony surface and rectiflexibiles spore type (Jain and Jain, 2006), while the colony of the five observed isolates are differently coloured, being respectively white, reddish white, greyish brown, greyish white, and beige, with nonsmooth colony surface when grown in ISP 2 media.

Table 3: DNA concentration of DGGE band from actinomycete community associated with Neofibularia sp.

\begin{tabular}{cc}
\hline $\begin{array}{c}\text { Number of } \\
\text { DGGE Band }\end{array}$ & DNA Concentration $(\mathrm{ng} / \mu \mathrm{L})$ \\
\hline Blank & -1.00 \\
1 & 9.30 \\
7 & 9.85 \\
14 & 8.75 \\
11 & 10.05 \\
3 & 10.25 \\
4 & 13.45 \\
5 & 19.95 \\
6 & 11.35 \\
9 & 11.10 \\
12 & 10.60 \\
13 & 10.65 \\
17 & 11.75 \\
20 & 10.75 \\
\hline
\end{tabular}

Based on the 16S rRNA gene sequences, the five culturable actinomycetes isolates have similarities with the following species of Streptomyces. Streptomyces sampsonii was first isolated from soil and has a rectiflexible spore chain, smooth colony surface, is thin and yellowish white when grown in ISP 2 medium. In addition, $S$. sampsonii produces heptaene antifungal compounds, a polyene antibiotic with fungal inhibition activity against Candida albicans, Aspergillus niger, Microsporum gypseum, and Trichophyton (Jain and Jain, 2006).

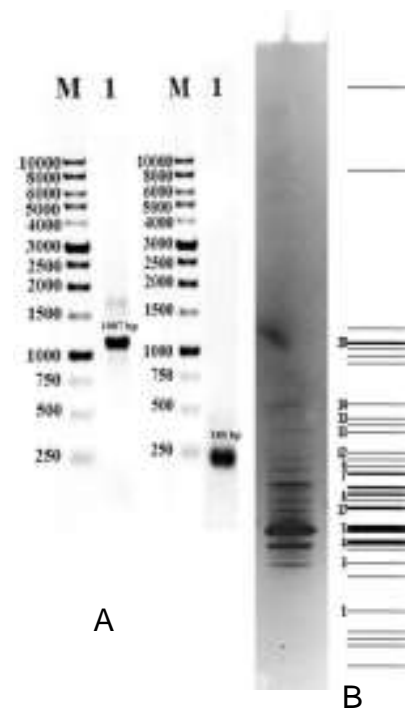

Figure 3: (A) PCR amplification of 16S rRNA (1087 bp amplicon) with primer 27F and 16Sact1114R, and second phase PCR amplification (180 bp amplicon) with primer p338F GC-clamp and p518R. Lanes: $1 \mathrm{~kb}$ marker (M); PCR amplicons (1). (B) DGGE analysis of 16S rRNA gene.

On the other hand, S. albus J1074 with light grey, brown, and greyish brown spores was first isolated from soil but is also found associated with marine sponges (Ian et al., 2014). Streptomyces albus inhibits pathogen activity of Fusarium solani and Helminthosporium oryzae, and also produces xylanase that are important for rice straw pulp fermentation (Rifaat et al., 2005). Streptomyces resistomycificus strain ISP 5133 produces resistomycin which are pentacyclic polyketides functioning in the apoptosis process of human CMK-7 leukimia megakaryoblastic cells (Shiono et al., 2002). Streptomyces erringtonii, first isolated from the remnant of pasture hays, is aerobic, non-acid resistant, and is characterised by divided substrate mycelia with greyish white aerial spores $(0.5-0.6 \times 0.8 \mu \mathrm{m})$ (Santhanam et al., 2013). Meanwhile, $S$. gougerotii, with rectiflexible spore chains and yellowish white spore surface when grown in ISP 2 medium, produces a gougerotin nucleoside antibiotic that has antibacterial and antivirus properties effected through the inhibition of peptide bond formation (Murao and Hayashi, 1983).

Identifications deduced from the NCBI database references that conflict with identifications based on morphological observations and other criteria are not uncommon. For example, in a study (Lisdiyanti et al., 2010), the results of molecular identification of Actinokineospora baliensis sp. nov., Actinokineospora cibodasensis sp. nov., and Actinokineospora cianjurensis sp. nov. indicated $98.2 \%$ similarity with Actinokineospora auranticolor and $99.4 \%$ with Actinokineospora terrae. However, based on chemotaxonomic analysis, DNA hybridization and morphological characteristics (phenotype), the species were deemed different from the 
reference strains, and they were eventually identified as a novel species. In our study, the actinomycetes associated with Neofibularia might similarly turn out to be novel species since the isolates had different colony characteristics from the reference strains, despite having 97 to $99 \%$ similarity in 16 S rRNA molecular identity with the five reference strains (Table 2 ).

\section{Structure of actinomycetes community associated with Neofibularia sp.}

The BLAST result for 13 DNA bands of actinomycetes associated with Neofibularia sp. indicated that the five actinomycetes groups that were identified belonged to rare actinomycetes, viz. Ferrithrix, Lamia, Aciditerrimonas, Thermobispora, and Propionibacterium. In addition, one DGGE band was not specifically identified using phylogenetic analysis. The number of actinomycetes isolates associated with Neofibularia sp. may be different for each actinomycetes community analysed, as indicated by the different thicknesses of DGGE bands. Such differences in populations of sponge-associated microbes are affected by factors such as sponge types and ages (Hentschel et al., 2003). Long term adaptation process, evolution, and sponge vertical transmission are conducive to the association between many bacteria and sponges (Lee et al., 2001).

Ferrithrix thermotolerans was first isolated from geothermal area of Yellowstone National Park, Wyoming, USA, and has small bacil cells $(3-4 \times 0.5 \mu \mathrm{m})$. It is a nonmotile, high-temperature tolerant bacterium with a $\mathrm{pH}$ optimum of 1.8. It is also a heterotroph capable of oxidising iron and sulphur (Johnson et al., 2009). Propionibacterium acnes strain KPA17202 is a non-sporic, anaerobic bacterium that favors a growth temperature of $37^{\circ} \mathrm{C}$. It is known to produce fatty acid isomerase (Liavonchanka et al., 2006). Lamia majanohamensis was first isolated from the sea cucumber Holothuria edulis collected from seawater off the coast of Japan (Midori et al., 2009). Aciditerrimonas ferrireducens strain IC-180 was first isolated from the solfataric zone of Hakone, Japan. It is capable of oxidising $\mathrm{H}_{2}$, and fixing $\mathrm{CO}_{2}$ under anaerobic conditions. While it is capable of reducing $\mathrm{Fe}^{3+}$, it is not capable of oxidising $\mathrm{Fe}^{2+}$ (Itoh et al., 2011). This actinomycete is also non-filament-forming and thermoacidophilic. Thermobispora bispora DSM 43833 is synonymous to Microbispora bispora which was first isolated from compost. Thermobispora bispora is known to have two different transcriptionally active $16 \mathrm{~S}$ rRNA genes, a feature not found in all microbes. The mycelia of T. bispora are monopodial and 0.5-0.8 $\mu \mathrm{m}$ in diameter. They have oval to round spores, and are non-motile (Wang et al., 1996).

The similarity of eight DNA bands with $F$. thermotolerans (with similarity up to $94 \%$ ) does not necessarily confirm their identity to the reference strain. In past research, a 16S rRNA sequence homology that has $<97.5 \%$ has subsequently been recognised as a distinct species (Stackebrandt and Goebel, 1994). It cannot be ruled out that in the present study, actinomycetes associated with Neofibularia sp. could include novel species different from $F$. thermotolerans strain Y005 despite close molecular similarities.

Again, this is true also for actinomycetes that can be classified as different species despite 16SRNA sequences that exceed $97.5 \%$ in similarity to a reference strain. For example, Streptomyces baliensis sp. nov., a novel actinomycetes species isolated from Indonesia, is considered a distinct species from Streptomyces glauciniger (98\% similarity), Streptomyces lilacinus $(97.6 \%)$, and Streptomyces abikoensis (97.7\%) despite close sequence consensus (Otoguro et al., 2009). Hence, the eight bands of unculturable actinomycetes associated with Neofibularia sp. which bear $94 \%$ similarity to the reference strains should be explored further for their species novelty. The novelty of actinomycetes can be fully determined through polyphasic taxonomy that is based on several characters such as morphology and physiological characters, chemotaxonomy, molecular analysis, i.e. 16S rRNA gene sequences and DNA hybridisation.

\section{Comparison of culturable and unculturable actinomycete diversity}

The culture and DGGE approaches adopted in the present study are used to assess the diversity of culturable an unculturable actinomycetes in parallel with the work of Zhang et al. (2006) and Xin et al. (2008). With the DGGE method, four rare actinomycetes were identified, while the cultivation technique recovered isolates came from a single genus, i.e. Streptomyces. It appears that the community of actinomycetes associated with Neofibularia are dominated by rare actinomycetes from the nonStreptomyces group. These bacteria that show similarity with Ferrithrix, Lamia, Aciditerrimonas, Thermobispora, and Propionibacterium cannot as yet be cultured for further characterization. On the other hand, the cultured isolates were not detected in the DGGE approach. This could be indicative of a very low abundance of Streptomyces spp. that failed to be amplified using DGGE primers (Sun et al., 2010). Possibly also, their presence could have been represented by very thin bands on the DGGE polyacrylamide gel, and they were not selected for sequencing. In our study, only 13 dominant bands out of 30 bands that appeared by phoretix analysis were sequenced. Therefore, the Streptomyces spp. might have been represented among the remaining 17 unsequenced bands. The present work can provide a foundation towards better understanding of the diversity of actinomycetes associated with sponge Neofibularia off Bira Island in the Indonesian archipelago. 


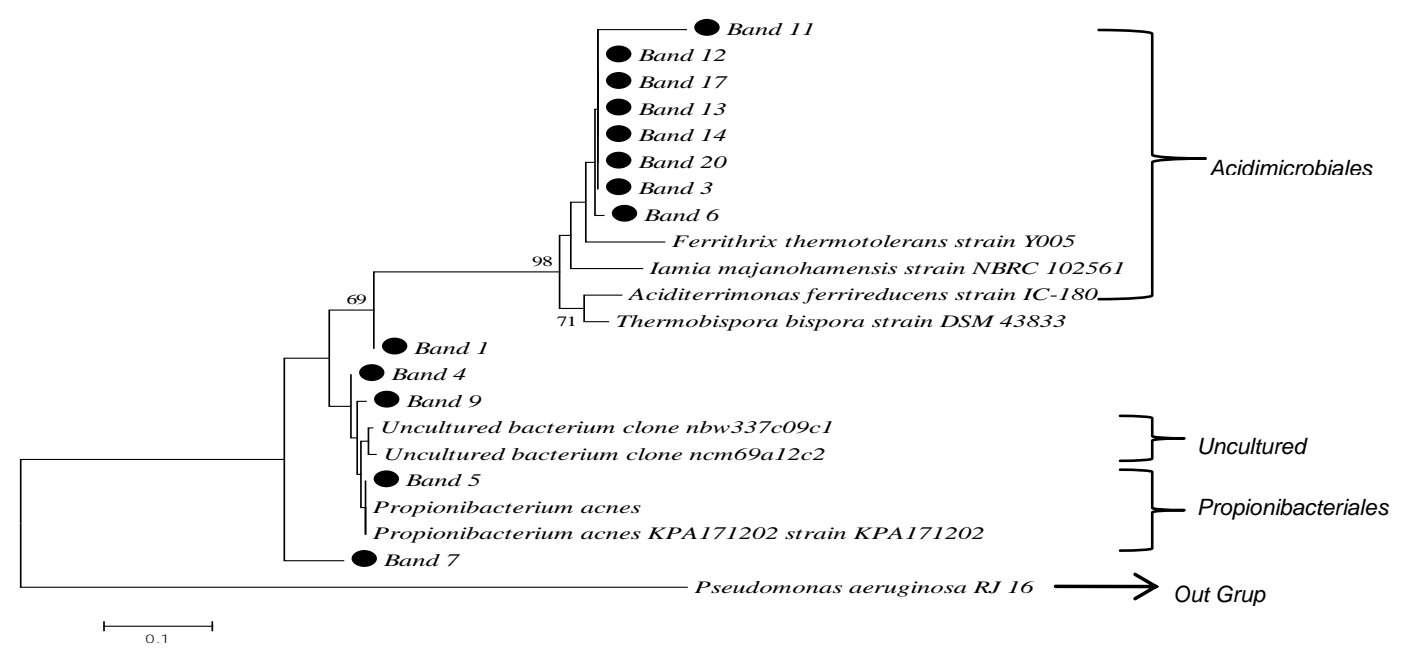

Figure 4: Phylogenetic tree based on DDGE separation of 16S rRNA gene of actinomycetes associated with Neofibularia sp. The phylogenetic tree was constructed using MEGA 6 software.

Table 4: Similarity of actinomycetes associated with Neofibularia sp. with GeneBank references strains, based on BLAST analysis of $16 S$ rRNA sequence.

\begin{tabular}{|c|c|c|c|c|c|c|}
\hline Band & Description & $\begin{array}{l}\text { Query } \\
\text { Cover }\end{array}$ & $\begin{array}{c}\text { Total Base } \\
\text { (GenBank/DGGE } \\
\text { Band) } \\
\end{array}$ & $\begin{array}{c}\text { Position } \\
\text { Ordinal } \\
\text { Base } \\
\end{array}$ & Identity & $\begin{array}{l}\text { Accession } \\
\text { Number }\end{array}$ \\
\hline \multirow[t]{2}{*}{1,4} & P. acnes strain KPA171202 & $100 \%$ & $130 / 128$ & $375-503$ & $94 \%$ & NR0746751 \\
\hline & P. acnes & $100 \%$ & $130 / 128$ & $375-503$ & $94 \%$ & NR0408471 \\
\hline \multirow[t]{2}{*}{5} & P. acnes strain KPA171202 & $97 \%$ & $130 / 128$ & $375-503$ & $100 \%$ & NR0746751 \\
\hline & P. acnes & $97 \%$ & $130 / 128$ & $375-503$ & $100 \%$ & NR0408471 \\
\hline 9 & P. acnes strain KPA171202 & $97 \%$ & $131 / 128$ & $375-503$ & $95 \%$ & NR0746751 \\
\hline \multirow{3}{*}{7} & $P$. acnes & $97 \%$ & $131 / 128$ & $375-503$ & $95 \%$ & NR0408471 \\
\hline & $\begin{array}{l}\text { Uncultured bacterium clone } \\
\text { nbw337c09c1 }\end{array}$ & $77 \%$ & $127 / 128$ & $357-482$ & $87 \%$ & GQ0907041 \\
\hline & $\begin{array}{l}\text { Uncultured bacterium clone } \\
\text { ncm69a12c2 }\end{array}$ & $77 \%$ & $127 / 128$ & $357-482$ & $86 \%$ & KF1082841 \\
\hline 13,12 & F. thermotolerans strain Y005 & $99 \%$ & $125 / 125$ & $381-508$ & $94 \%$ & NR0427511 \\
\hline \multirow[t]{3}{*}{14,17} & $\begin{array}{l}\text { L. majanohamensis strain NBRC } \\
102561\end{array}$ & $99 \%$ & $125 / 125$ & $359-486$ & $92 \%$ & NR0416341 \\
\hline & A. ferrireducen strain IC-180 & $100 \%$ & $125 / 126$ & 366-494 & $92 \%$ & NR1129721 \\
\hline & T. bispora strain DSM 43833 & $100 \%$ & $125 / 126$ & $390-518$ & $92 \%$ & NR0746801 \\
\hline \multirow[t]{4}{*}{20} & F. thermotolerans strain Y005 & $99 \%$ & $123 / 125$ & $381-508$ & $92 \%$ & NR0427511 \\
\hline & $\begin{array}{l}\text { L. majanohamensis strain NBRC } \\
102561\end{array}$ & $99 \%$ & $123 / 125$ & $359-486$ & $90 \%$ & NR0416341 \\
\hline & A. ferrireducen strain IC-180 & $100 \%$ & $123 / 126$ & $366-494$ & $91 \%$ & NR1129721 \\
\hline & T. bispora strain DSM 43833 & $100 \%$ & $123 / 126$ & $390-518$ & $91 \%$ & NR0746801 \\
\hline \multirow[t]{4}{*}{6} & F. thermotolerans strain Y005 & $99 \%$ & $125 / 125$ & $381-508$ & $93 \%$ & NR0427511 \\
\hline & $\begin{array}{l}\text { L. majanohamensis strain NBRC } \\
102561\end{array}$ & $99 \%$ & $125 / 125$ & $359-486$ & $92 \%$ & NR0416341 \\
\hline & A. ferrireducen strain IC-180 & $100 \%$ & $125 / 126$ & $366-494$ & $91 \%$ & NR1129721 \\
\hline & T. bispora strain DSM 43833 & $100 \%$ & $125 / 126$ & $390-518$ & $91 \%$ & NR0746801 \\
\hline \multirow[t]{3}{*}{3} & F. thermotolerans strain Y005 & $97 \%$ & $125 / 125$ & $381-508$ & $93 \%$ & NR0427511 \\
\hline & $\begin{array}{l}\text { L. majanohamensis strain NBRC } \\
102561\end{array}$ & $97 \%$ & $125 / 125$ & $359-486$ & $92 \%$ & NR0416341 \\
\hline & $\begin{array}{l}\text { A. ferrireducen strain IC- } 180 \\
\text { T. bispora strain DSM } 43833\end{array}$ & $\begin{array}{l}98 \% \\
98 \%\end{array}$ & $\begin{array}{l}125 / 126 \\
125 / 126\end{array}$ & $\begin{array}{l}366-494 \\
390-518\end{array}$ & $\begin{array}{l}92 \% \\
92 \%\end{array}$ & $\begin{array}{l}\text { NR1129721 } \\
\text { NR0746801 }\end{array}$ \\
\hline \multirow[t]{4}{*}{11} & F. thermotolerans strain Y005 & $100 \%$ & $128 / 125$ & $381-508$ & $88 \%$ & NR0427511 \\
\hline & $\begin{array}{l}\text { L. majanohamensis strain NBRC } \\
102561\end{array}$ & $100 \%$ & $128 / 125$ & $359-486$ & $87 \%$ & NR0416341 \\
\hline & A. ferrireducen strain IC-180 & $100 \%$ & $128 / 126$ & $366-494$ & $87 \%$ & NR1129721 \\
\hline & T. bispora strain DSM 43833 & $100 \%$ & $128 / 126$ & $390-518$ & $85 \%$ & NR0746801 \\
\hline
\end{tabular}




\section{CONCLUSION}

This is the first study of the community structure of actinomycetes associated with Neofibularia sp. The community of actinomycetes comprises both culturable and unculturable actinomycetes. The combined culture and DGGE approaches provide an informative appraisal of the actinomycete diversity that includes rare actinomycetes identified through the latter procedure. Of this group, eight DGGE bands had the highest similarity of $94 \%$ with $F$. thermotolerans strain Y005, four bands were most similar $(97-100 \%)$ to $P$. acnes strain KPA171202, and one band had the highest similarity of $77 \%$ with uncultured bacterium clone nbw337c09c1. The culturable actinomycetes isolated in this study were all from the Streptomyces group, and were most similar (97-99\%) to S. sampsonii strain NRRL B12325, S. resistomycificus strain ISP 5133, and S. albus strain J1074.

\section{ACKNOWLEDGEMENTS}

The authors aknowledge the support of Directorate General of Higher Education, Ministry of Research, Technology and Higher Education, Indonesia, through a research grant awarded to Yulin Lestari, and an academic scholarship awarded to Chico Jhon Karunia Simamora.

\section{REFERENCES}

Drummond, A. K. (2006). Bioactive metabolites from microorganism. PhD. Thesis. University Of North Carolina Wilmington, U. S.

Fischer, S. G. and Lerman, L. S. (1983). DNA fragments differing by single base pair substitutions are separated in denaturing gradien gels: Correspondence with melting theory. Proceedings of the National Academy of Sciences of the United States of America 80, 1579-1583.

Hentschel, U., Fieseler, L., Wehrl, M., Gernert, C., Steinert, M., Hacker, J. and Horn, M. (2003). Microbial diversity of marine sponges. Progress in Molecular and Subcellular Biology 37, 59-88.

Hentschel, U., Piel, J., Degnan, S. M. and Taylor, M. W. (2012). Genomic insights into the marine sponge microbiome. Nature Reviews Microbiology 10, 641654.

Hutomo, M. and Moosa, M. K. (2005). Indonesian marine and coastal biodiversity: Present status. Indian Journal of Marine Sciences 34, 88-97.

Ian E., Malko, D. B., Sekurova, O. N., Bredholt, H., Ruckert, C., Borisova, M. E., Albersmeier, A., Kalinowski, J., Gelfand, M. S. and Zotchev, S. B. (2014). Genomic of sponge-associated Streptomyces spp. closely related to Streptomyces albus J1074: Insight into marine adaptation and secondary metabolite biosynthesis potential. Plos One 9, e96719.

Itoh, T., Yamanoi, K., Kudo, T., Ohkuma, M. and Takashina, T. (2011). Aciditerrimonas ferrireducens gen. nov., sp. nov., an iron-reducing thermoacidophilic actinobacterium isolated from a solfataric field.
International Journal of Systematic and Evolutionary 61, 1281-1285.

Jain, P. K. and Jain, P. C. (2006). Isolation, characterzation and antifungal activity of Streptomyces sampsonii GS 1322. Indian Journal of Experimental Biology 45, 203-206.

Johnson, D. B., Nicolau, P. B., Okibe, N., Thomas, A. and Hallberg, K. B. (2009). Ferrimicrobium acidiphilum gen. nov., sp. nov. and Ferrithrix thermotolerans gen. nov., sp. nov.: Heterotrophic, ironoxidizing, extremely acidophilic actinobacteria. International Journal of Systematic and Evolutionary 59, 1082-1089.

Learn-Han, L., Yoke-Kqueen, C., Shiran, M. S., VuiLing, C. M. W., Nurul-Syakima, A. M., Son, R. and Andrade, H. M. (2012). Identification of actinomycetes communities in antarctic soil from Barrientos Island using PCR-denaturing gradien gel electrophoresis. Genetics and Molecular Research 11, 277-291.

Lee, Y. K., Lee, J. H. and Lee, H. K. (2001). Microbial symbiosis in marine sponges. Journal of Microbiology 39, 254-264.

Liavonchanka, A., Hornung, E., Feussner, I., and Rudolph, M. G. (2006). Structure and mechanism of the Propionibacterium acnes polyunsaturated fatty acid isomerase. Proceedings of the National Academy of Sciences of the United States of America 103, 25762581.

Lisdiyanti, P., Otoguro, M., Ratnakomala, S., Lestari, Y., Hastuti, R. D., Triana, E., Katsuhiko, A. and Widyastuti, Y. (2010). Actinokineospora baliensis sp. nov., Actinokineospora cibodaensis sp. nov., and Actinokineospora cianjurensis sp. nov., isolated from soil and plant litter. International Journal of Systematic and Evolutionary Microbiology 60, 2331-2335.

Martina, K., Jan, K., Tamas, F., Ladislav, C., Marek, O., Genevieve, L. G., Yvan M. L. and Marketa, S. M. (2008). Development of a 16S rRNA gene based prototype microarray for the detection of selected actinomycetes genera. Antonie Van Leeuwenhoek International Journal 94, 439-453.

Midori, K., Yukiyo, F., Yayoi, S., Shigeaki, H. and Akira, Y. (2009). Lamia majanohamensis gen. nov., sp. nov., an actinobacterium isolated from sea cucumber Holothuria edulis, and proposal of lamiaceae fam. nov. International Journal of Systematic and Evolutionary Microbiology 59, 869-873.

Murao, S. and Hayashi, H. (1983). Gougerotin, as a plant growth inhibitor, from Streptomyces sp. Agricultural and Biological Chemistry 47, 1135-1136.

Muyzer, G., Waal, E. C. and Uitierlinden A. G. (1993). Profiling of complex microbial populations by denaturing gradient gel electrophoresis analysis of polymerase chain reaction amplified genes coding for $16 \mathrm{~s}$ rRNA. Applied and Environmental Microbiology 59, 695-700.

Otoguro, M., Ratnakomala, S., Lestari, Y., Hastuti, R. D., Triana, E., Widyastuti, Y. and Ando, K. (2009). Streptomyces baliensis sp. nov., isolated from 
Balinese soil. International Journal of Systematic and Evolutionary Microbiology 59, 2158-2161.

Overeas, L., Fomey, L. and Daae, F. L. (1997). Distribution of bacterioplankton in meromictic Lake Saelevannet, as determined by denaturing gradient gel electrophoresis of PCR-amplified gene fragments coding for $16 \mathrm{~S}$ rRNA. Applied and Environmental Microbiology 63, 3367-3373.

Pathirana, C., Jensen, P. R. and Fenical, W. (1992). Marinone and debromomarinone, antibiotic sesquiterpenoid napthoquinone of a new structural class from marine bacterium. Tetrahidron Letters 33, 7663-7666.

Peraud, O. (2006). Isolation and Characterization of a sponge-associated actinomycetes that produces manzamines. PhD. Disertation. University of Maryland, U. S.

Rifaat, H. M., Nagieb, Z. A. and Ahmed, Y. M. (2005). Production on xylanase by Streptomyces species and their bleaching effect on rice straw pulp. Applied Ecology Environmental Research 4, 151-160.

Saitou, N. and Nei, M. (1987). The neighbor-joining method: A new method for reconstructing phylogenetic trees. Molecular Biology and Evolution 4, 406-425.

Santhanam, R., Rong, X., Huang, Y. and Goodfellow, M. (2013). Streptomyces erringtonii sp. nov. and Streptomyces kaempferi sp. nov., isolated from a hay meadow soil. Antonie Van Leeuwenhoek International Journal 103, 79-87.

Shick, J. M. and Dunlap, W. C. (2002). Mycosporine-like amino acids and related gadusols: Biosynthesis, acumulation, and UV-protective functions in aquatic organisms. Annual Review of Physiology 64, 223-262.

Shiono, Y., Shiono, N., Seo, S., Oka, S. and Yamazaki, Y. (2002). Effects of polyphenolic anthrone derivatives, resistomycin and hypericin, on apoptosis in human megakaryoblastic leukemia CMK-7 cell line. Zeitschrift fur Naturforschung 57, 923-929.

Shirling, E. B. and Gottlieb, D. (1966). Methods for characterization of Streptomyces species. International Journal of Systematic Bacteriology 16, 313-340.

Stackebrandt, E. and Goebel, B. M. (1994). Taxonomic note: a place for DNA-DNA reassociation and 16S rRNA sequence analysis in the present species definition in bacteriology International Journal of Systematic and Evolutionary Microbiology 44, 846849.

Sun, W., Dai, S. and Jiang, S. (2010). Culture-dependent and culture-independent diversity of actinobacteria associated with the marine sponge Hymeniacidon perleve from the South China Sea. Antonie Van Leeuwenhoek International Journal 98, 65-75.

Thompson, M. N. and Gallimore, W. (2013). Antileishmanial, antimalarial and antimicrobial activity of the Jamaican 'Touch-me-not' sponge Neofibularia nolitangere. Journal of Applied Pharmaceutical Science 3, 80-83.

Vieira, F. C. S. and Nahas, E. (2005). Comparison of microbial numbers in soils by using various culture media and temperatures. Microbiological Research 160, 197-202.

Wang, Y., Zhang, Z. and Ruan, J. (1996). A proposal to trasfer Microbispora bispora (Lechevalier 1965) to a new genus, Thermobispora gen. nov., as Thermobispora bispora comb. nov. International Journal of Systematic Bacteriology 46, 933-938.

Webster, N. S., Wilson, K. J., Blackall, L. L. and Hill, R. T. (2001). Phylogenetic diversity of bacteria associated with the marine sponge Rhopaloeides odorabile. Applied and Environmental Microbiology 67, 434-444.

Xin, Y., Huang, J., Deng, M. and Zhang, W. (2008). Culture-independent nested PCR method reveals high diversity of actinobacteria associated with the marine sponges Hymeniacidon perleve and Sponge sp. Antonie Van Leeuwenhoek International Journal 94, 533-542.

Zhang, H., Lee, Y. K., Zhang, W. and Lee, H. K. (2006). Culturable actinobacteria from the marine sponge Hymeniacidon perleve: Isolation and phylogenetic diversity by $16 \mathrm{~S}$ rRNA gene-RFLP analysis. Antonie Van Leeuwenhoek International Journal 90, 159-169.

Zhang, W., Long, X., Huo, X., Chen, Y., and Lou, K. (2013). 16S rRNA-based DGGE analysis of actinomycetes communities in fields with continuous cotton cropping in Xinjiang, China. Microbial Ecology 66,385-393. 